\title{
The Appellate Body is Shut Down, How to Break the Deadlock
}

\author{
Wang simin* \\ Law school of Shandong University, Shandong, Qingdao 266237, China \\ *Corresponding author.Email: zeternalx@163.com
}

\begin{abstract}
On December 11 th, the World Trade Organization Appellate Body was shut down because of an insufficient number of judges. It was the first shutdown in nearly 25 years and a serious crisis in the history of the WTO. This paper introduces and evaluates some existing suggestions on how to get out of the deadlock, and analyzes the feasibility of these suggestions.Finally, the author makes a suggestion: the establishment of a new appeals body whose functions should complement the existing dispute settlement mechanism Keywords: World Trade Organization, Appellate Body, shutdown, dispute settlement mechanism, new Appellate Body
\end{abstract}

\section{INTRODUCTION}

Due to the relatively complete and clear legal provisions and the fair handling of trade disputes between member states in the past few decades, WTO dispute settlement mechanism has always played an important role in the trend of economic globalization[1] and is a quasi-judicial mechanism trusted and respected by member states. Among institutions of dispute settlement body(DSB) of WTO, the Appellant Body is the last defense line to deal with trade disputes between countries fairly, and it is also the most characteristic and advantageous system compared to other international dispute settlement mechanisms. However, at present, the Appellate Body has encountered an unprecedented dilemma: for the first time it shut down since it inception. If the Appellate Body has been suspended for a long time and member states are unable to find any solution, it may pose a risk to the WTO system as a whole. In order to find a solution to this crisis, this paper proposes to establish a new Appellate Body with the function of and parallel with the existing dispute settlement mechanism. The first part of this paper introduces the current dispute settlement procedure of WTO and the difficulties it faces. The second part describes the possible results if the dispute is still submitted to the DSB after the Appellate Body is shut down. The third part discusses the solutions to the current deadlock and their corresponding evaluation. The fourth part summarizes the current stalemate, clarifies the significance of the Appellant Body to the multilateral trading system as a whole, and calls for an early resolution of the problem.

\subsection{Current WTO dispute settlement procedures}

There are following procedures in the existing dispute settlement mechanism of WTO: consultation procedure, mediation procedure, arbitration procedure, expert group hearing procedure and Appellate Body review procedure. Not every case is solved by all procedures. However, in practice, with the development of global economy and science and technology, the types and quantity of trade goods have greatly increased, the interests of various countries have become more and more complex, more and more cases have come to the point of being reviewed by Appellant Body.

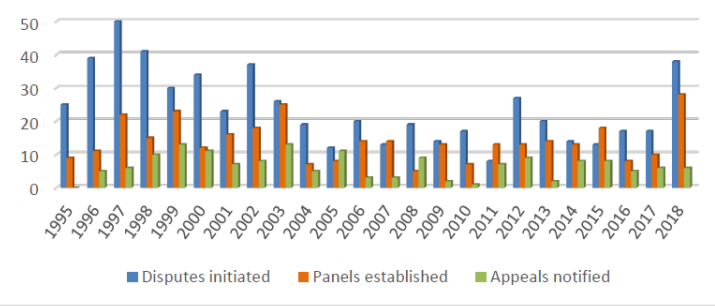

Figure 1 the number of disputes filed annually for WTO from 1995 to 2018 and the number of appeals to expert groups and appellate bodies:

For reports in the case of a report made by the Group of Experts after the proceedings of the Group of Experts, if either party of the dispute has any party to the legal or legal interpretation of the report, it shall submit an appeal notice to the Appellate Body established by the DSB within 60 days of the receipt of the report of the Group of Experts.[2] The Appellate Body has a panel of seven judges for a term of four years each, requiring at least three judges in each case.[3] The report of the Appellate 
Body is the final decision. The adoption of the report of the Appellate Body adopts a reverse-consistent principle.[4]

\subsection{The current predicament}

At present, the Appellate Body has encountered an unprecedented dilemma: Since 2016, the United States has used the principle of adoption by consensus to block the re-election of member of the appellant, Zhang Shenghe (the principle of consensus has been adopted in the selection of members of the Appellant Body) because it believes that the case adjudicated by Judge Zhang Shenghe in the Appellate Body is detrimental to the interests of the United States.[5] Besides, the United States refused to start the election of members of the Appellate Body by using the principle of adoption by consensus, which caused the numbers of members of the Appellate Body decreasing from 2016.[6] As of 11 December, two of the remaining three judges arrived for a term of office, with only one remaining judge called Zhaohong in the Appellate Body. It can be said that the Appellant Body has been shut down because it is unable to meet the minimum number of appeals. The Appellant Body that acts as the last line of defense is shut down, whether DSB, which is called the "The Pearl on the Crown", will be overshadowed? What to do with the reform of the WTO? How to keep the civilization of DSB and avoid the danger of international trade in the "rule of the jungle" after the appeal has been suspended?

\section{RESULTS}

\subsection{Possible consequences when using DSB to solve disputes in current situation}

Although the Appellate Body is suspended now, it does not mean that the DSB is completely paralysed, and the parties to the dispute can still refer the dispute to the DSB for settlement. Any case reported to the DSB may have the following:

\subsubsection{The dispute was settled in a consultative process prior to the panel's consideration}

According to Article 4 of DSU, the parties to the dispute must first settle the dispute through consultation[7]. When a member considers that another member violates or does not comply with the Marrakech Agreement, thereby harming itself, it may request consultation with the other party and shall notify the DSB and the relevant council or committee. The members of the requested consultations shall respond within 10 days of the date of receipt of the request for consultations and shall consult on a time not exceeding 30 days after the date of receipt of the request. [8]The consultation shall be completed within 60 days after the date of the request for consultation. if that member has not reply within 10 days after the date of receipt of the request, or no consultation has been held within 30 days of the date of receipt of the request, or after receiving the request for consultation for 35 days, the two parties agree that no consultation is reached, or no consultation is reached within 60 days of the date of receipt of the request for consultation, the complainant may file an application to the DSB to set up an expert group. If the parties to the dispute reach agreement within the prescribed time limit, there is no need for the intervention of the panel of experts, nor for the panel to issue a report, and there is no longer a need for the Appellant Body to consider the legal issues contained in the report of the panel of experts. In such cases, the shutdown of the Appellant Body will not have an impact on the settlement of the dispute.

\subsubsection{Case arrives at the Appellate Body}

However, in practice, the vast majority of cases have been heard by the Group of experts and reached the Appellate Body. Once the case has gone through the proceedings of the panel of experts and the report of the jury has been issued, the following two results will arise: First, the DSB approves the report of the panel, unless the report of the panel is not adopted by consensus; the other is that within 60 days, either or both parties to the dispute file an appeal, so that the report of the panel does not enter into force and the dispute settlement enters the appeal stage; In the first case, the jury report was adopted, and the parties to the dispute agreed that the appeal body was no longer required to intervene. (the adoption of the jury report adopted the principle of reverse agreement.) in the first case, the jury report was adopted and the parties to the dispute reached agreement and there is no need to require the intervention of the Appellate Body. In the second case, however, as a result of the shutdown of the Appellant Body, the following two additional results may arise: 1 . Although a party to the disputes believe that there are some errors refers to legal issues or legal facts in the report of jury, it is not possible to prevent the passage of the report due to the adoption of the principle of reverse agreement in the report of the jury. Besides, as a result of the shutdown of the Appellant Body, the contender was unable to appeal to the Appellant Body for final decision. 2. The parties to the dispute are of the opinion that there is a legal or legal error in the report of the jury and, therefore, the passage of the report is prevented by a reverse-consistent means. The Panel's report was not available at this time.

Thus it can be seen that the first of the above two cases is the most satisfactory: the report of the jury comes into force, the parties to the dispute reach agreement, and the dispute settlement mechanism is not much affected; in the second case, the dispute has not been resolved: Whether it is due to the dissatisfaction of one party to the dispute and the suspension of the Appellate Body made it impossible to help it, or whether the parties are not satisfied with the adoption of the report. In the second case, the first result 
would be controversial and even shake the foundations of the multilateral trading system; the second would be a helpless outcome that would gradually deprive confidence of WTO members in the multilateral trading system. Therefore, in the second case, the results are contrary to the purpose of WTO dispute settlement established in Article 3 (2) of DSU.[9]

The above analysis shows that the outcome of more cases will be in an uncertain state, with the exception of a small number of dispute cases that can be resolved through consultation procedures or agreed by both parties through the jury report after the Appellant Body is "shut down". If such a phenomenon has been spreading, not only will the WTO be re-return to the "power-oriented" jungle rule, the multilateral trading system will also face the danger of disintegration.It can therefore be expected that, in the future, member states of WTO may take other means to resolve disputes among them or try to save Appellate Body of DSB.

\section{DISCUSSION}

\subsection{Solutions to maintain the multilateral trading system}

\subsubsection{Revitalize the trade regionalism}

After the shutdown of the Appellant Body, the parties may turn to other means of dispute settlement to resolve disputes arising in international trade. For example, Revitalize the trade regionalism: Regulate rules in regional preferential trade agreements to address possible disputes in member States during the trade process.[10] As early as July 2018, the EU and Japan have taken the lead in the free-trade agreement, and the two sides will cancel almost all tariffs and create the world's largest free trade area. The United States has also shifted the focus of its trade policy to bilateral or regional agreements that are more favourable to it. The United States has completed renegotiation of the North American Free Trade Agreement with Canada and Mexico and reached the United States-Mexico-Canada Agreement on October 1, 2018. At the same time, the United States has reached a preliminary intention with the European Union and Japan to establish a free trade zone.

In fact, in recent years, trade regionalism has become a popular practice, driven by complex economic and political motives, part of the reason is the slow progress of WTO reform negotiations. Trade regionalism may be one of the solutions to the current DSB stalemate after the appellant shutdown. However, in practice, regional dispute settlement mechanisms are rarely applied. Most of the parties to regional agreements are WTO members, who may prefer WTO's dispute settlement mechanism. The advantage of WTO dispute settlement mechanism is that it provides all members with a relatively definite interpretation of the legal text. In addition, the WTO dispute settlement mechanism has adjudicated hundreds of cases and gradually established good credibility, and it is difficult for regional dispute settlement mechanisms to compete with them in a short period of time. In short, trade regionalism might be a substitute for multilateralism in some ways, but it would not be a complete substitute.

\subsubsection{Reform Appellate Body or revise the principle of adoption by consensus}

Some WTO member states may want to reform Appellate Body or revise the principle of adoption by consensus to make the suspended Appellate Body re-operational. As mentioned earlier, if the suspended Appellate Body reoperates, it is necessary to ensure that the number of judges of the appeal body is greater than or equal to three. The current stalemate is that the United States uses the principle of adoption by consensus to veto the selection system of judges, leaving fewer than three judges and making the Appellant Body unoperational. How can this stalemate be broken?

\subsubsection{Reform Appellate Body}

The first method is to respond to and reform the problems of WTO put forward by the United States, and finally get a satisfactory solution, and then make the appellant refunction through the selection of appellants.[11] A year ago, the corresponding solutions were put forward by some countries: the Concept Paper and China EU joint proposal, which have put forward the same and relatively clear solutions to the reform of appeal body, and the discussion paper proposed by the Canadian party also contributed some suggestions. These reform programmes or recommendations, to a large extent, are to respond to the dissatisfaction of the United States with the Appellate Body and, of course, also include some of the demands of other WTO members to guarantee the independence and functioning of the Appellate Body. If the members of the WTO, especially the United States, recognize the corresponding reform proposals of the Appellate Body, then it is possible to adopt the principle of agreement, to conduct the selection of the judges of the Appellate Body and to re-operate the suspension of the Appellate Body. In practice, however, it is difficult to obtain the support of the United States, even if the corresponding reform is carried out because it has used a one-vote veto 29 times in two years to prevent the selection of new members of the Appellate Body.[12]

\subsubsection{Revise regulations}

Another way to reactivate the closed Appellant Body is to revise some regulations, making the selection of the 
members of the Appellate Body does not require the consensus of all members. If the selection of the members of the Appellant Body is changed to the principle of reverse consistency or minority obedience to the principle of majority, the problem can be solved and the Appellant Body can resume its operation. However, in accordance with article 10, paragraph 8, of the Marrakech Agreement for the Establishment of the World Trade Organization: "any member of the WTO may submit proposals to amend the provisions of multilateral trade agreements listed in annexes 2 and 3, which shall be submitted to the Ministerial Conference for approval. Decisions on amendments to multilateral trade agreements listed in Annex 2 shall be taken by consensus. ". This provision clearly stipulates that amendments to the dispute settlement mechanism must be made by "consensus". Therefore, in order to amend the principle of "consensus" selected by the members of the Appellant Body, the consent of the United States must also be obtained, but from the point of view of the performance of the United States It is undoubtedly impossible in the near future.

\subsubsection{Re-examine the WTO rules}

Some WTO states members may would like to re-examine the WTO rules,applying the existing WTO rules to find a way to break the current deadlock: Using arbitration as an alternative to the Appellant Body. In the DSU, articles relating to arbitration include article 21, paragraph 3,[13] article 22, paragraph 6 , and article 25, [14] of these, article 21 , paragraph 3 , provides for a reasonable period of time, and article 22, paragraph 6, provides for issues of procedures and principles, and only article 25 provides for arbitration as a means of resolving disputes on the basis of both parties to the dispute. However, the feasibility of such a solution has not been high enough to constitute "effective" competition and substitution for expert group (or expert group and Appellate Body) proceedings over the past few decades. There are two main reasons for this phenomenon:1. Article 25 of the DSU provides for arbitration in a rather crude manner. 2. From its own point of view, DSB does not prohibit WTO members from circumventing the first instance jury procedure and directly using arbitration to hear disputes, but the system is not feasible in practice, because the appeal mechanism and enforcement mechanism behind DSU are all cases that originated from the jury. Article 22, paragraph 6, of the DSU also recommends that the members of the arbitral tribunal be the best judge of the case, as they are aware of the merits of the case. As a result, it can be seen that, although the DSU does not exclude the legal issues of the dispute between the two parties, the WTO member is unlikely to prefer the arbitration as an alternative to an appeal, based on the inherent defects of the system.

\subsection{New proposal: the establishment of new Appellate Body}

It is undeniable that the WTO dispute settlement mechanism has played a very important role in solving international trade disputes over the past few decades and maintaining the stability of global trade. The author believes that the establishment of a new Appellate Body is a solution to the current difficult situation.

It should be determined that the appearance of the new Appellate Body does not mean the abandonment of the original Appellate Body and the Group of Experts, which, in addition to the original Appellate Body, serves other member States that are willing to settle the dispute through the Appellate Body. The original panel proceedings are still carried out, and once one or both parties to the dispute consider that there are legal issues or legal interpretation of the report submitted by the panel of experts, if both parties to the dispute are States that agree to the establishment of a new Appellant Body, they may submit it to the new Appellate Body for trial and final decision. In order to avoid the suspension of the deadlock caused by the lack of the number of idioms in the Appellate Body, the selection of new members of the Appellate Body should follow the principle of the majority rule and not the original principle of adoption by consensus. If one or both of the parties to the dispute are States that do not agree to the establishment of a new Appellate Body, they may take other dispute resolution methods to resolve the dispute.

Why should a new Appellate Body be established rather than to reform the original Appellate Body? In the author's opinion, there are the following reasons:

1.If the original Appellate Body is reformed and it is required to resume its operation, there is only one method: Modify the principle of adoption by consensus in the selection of members of the Appellate Body, Which is currently impossible as the approach involves the modification of the DSU clause. However, in accordance with the provisions of Article 2 of the DSU[15], the modification of the DSU requires the consensus of all members.

2.To set up a new Appellant Body, there must be a solid legal basis.Member States should develop corresponding legal agreements to support the establishment of new appellate bodies The modification of the original appeal body needs to be modified as the DSU clause of its legal basis, which is no doubt impossible in the present case, but the establishment of a new Appellate Body does not need to be bound in the current WTO agreement, and can take the form of jumping out of the WTO framework. Outside the WTO agreement, Member States willing to establish new appellate bodies enter into agreements voluntarily and these agreements should belong to a multilateral international treaty between countries.

The establishment of the new Appellate Body avoids the existing WTO dispute settlement mechanism become paralysed and loses the civilization. It should still apply to the existing fairly mature dispute settlement rules of the WTO. Besides, the new Appellant Body still belongs to 
[4]: According to DSU Article 17, paragraph 14. https://www.wto.org/english/docs_e/legal_e/28dsu_e.htm\#17. (“An Appellate Body report shall be adopted by the DSB and unconditionally accepted by the parties to the dispute unless the DSB decides by consensus not to adopt the Appellate Body report within 30 days following its circulation to the Members...")

As the permanent body in the WTO dispute settlement body, the Appellate Body has played a vital role in the effective settlement of international trade disputes in the past decades. The Appellate Body is now in the midst of an unprecedented crisis: For the first time it has closed since its inception. If the Appellate Body is suspended for a long time and member states are unable to find any solution, the dispute settlement parties can only settle trade disputes through diplomatic consultations and national strength. Indian Judge Batia, the newly retired appellant, said this would lead to "any failure to prevent the report from being passed by submitting the panel report to the paralyzed Appellate Body", which would "bring us back to the GATT era." The EU's concept paper also points out that, if the DSB Appellate Body has been paralysed for a long time, it is equivalent to a 20 -year setback of global economic governance. Rule is only useful in a convenient environment, and the strength will replace the rule as the basis of trade relations. More serious, the prolonged vacancy of the Appellate Body may pose a risk to the WTO system as a whole. Therefore, in the case of the current shutdown of the WTO Appellate Body, it is particularly important to break the deadlock. Whether it is to re-seek other dispute solutions or to bring the Appellant Body back into operation in a variety of ways or even to set up a new Appellate Body, the aim of all these proposals is to maintain the stability of the multifaceted trading system and to prevent the WTO from returning to the era of "power-oriented" jungle rule.

\section{REFERENCES}

[1]:According to WTO Website: Dispute Settlement. https://www.wto.org/english/tratop_e/dispu_e/dispu_e. htm ("The WTO has one of the most active international dispute settlement mechanisms in the world.")

[2]: According to DSU Article 17, paragraph 5. https://www.wto.org/english/docs_e/legal_e/28dsu_e.htm\#17.(“As a general rule, the proceedings shall not exceed 60 days from the date a party to the dispute formally notifies its decision to appeal to the date the Appellate Body circulates its report.")

[3]: According to Article 17, paragraph 1, of the DSU. https://www.wto.org/english/docs_e/legal_e/28dsu_e.htm\#17. ("The Appellate Body shall hear appeals from panel cases. It shall be composed of seven persons, three of whom shall serve on any one case..." )
[5].Dan Ikenson, US Trade Laws and The Sovereignty Canard,(Forbes,March,2017).

https://www.forbes.com/sites/danikenson/2017/03/09/us-trade-laws-and-the-sovereignty-

canard/\#4ed2bb58203f.

[6].Rejects Plan to Break Trade Court Deadlock, THE STRAITS TIMES(Geneva, April 27, 2018).

https://www.straitstimes.com/world/europe/us-rejectsplan-to-break-trade-court-deadlock.

[7] : According to Article 4, paragraph 1 of the DSU. https://www.wto.org/english/docs_e/legal_e/28-

dsu_e.htm\#4. (" Members affirm their resolve to strengthen and improve the effectiveness of the consultation procedures employed by Members.")

Article 4, paragraph 2: ("Each Member undertakes to accord sympathetic consideration to and afford adequate opportunity for consultation regarding any representations made by another Member concerning measures affecting the operation of any covered agreement taken within the territory of the former.")

[8] : According to Article 4, paragraph 3, of the DSU https://www.wto.org/english/docs_e/legal_e/28-

dsu_e.htm\#4. ("If a request for consultations is made pursuant to a covered agreement, the Member to which the request is made shall, unless otherwise mutually agreed, reply to the request within 10 days after the date of its receipt and shall enter into consultations in good faith within a period of no more than 30 days after the date of receipt of the request, with a view to reaching a mutually satisfactory solution. If the Member does not respond within 10 days after the date of receipt of the request, or does not enter into consultations within a period of no more than 30 days, or a period otherwise mutually agreed, after the date of receipt of the request, then the Member that requested the holding of consultations may proceed directly to request the establishment of a panel.")

[9] : According to DSU Article 3(2). https://www.wto.org/english/docs_e/legal_e/28-

dsu_e.htm\#3. ("The dispute settlement system of the WTO is a central element in providing security and predictability to the multilateral trading system...")

[10]: Lester S , Mercurio B . Bilateral and Regional Trade Agreements (Commentary and Analysis) \| 
Bilateral and plurilateral PTAs[J]. 2009, 10.1017/CBO9780511575983(4):52-78.

[11]: Hoekman B . Proposals for WTO reform : a synthesis and assessment[J]. Social Science Electronic Publishing, 2011.

[12]: "One veto is used 29 times in two years! The obstruction by the United States will lead to the suspension of the "Supreme Court" of international trade".China Youth Network .2019.12.09

https://baijiahao.baidu.com/s?id=165241702899636931 $2 \& w f r=$ spider $\&$ for $=\mathrm{pc}$

[13]: According to Article 21, paragraph 3 of DSU. https://www.wto.org/english/docs_e/legal_e/28-

dsu_e.htm\#21. ( "At a DSB meeting held within 30 days(11) after the date of adoption of the panel or Appellate Body report, the Member concerned shall inform the DSB of its intentions in respect of implementation of the recommendations and rulings of the DSB. ")

[14]: According to Article 25 of DSU: https://www.wto.org/english/docs_e/legal_e/28-

dsu_e.htm\#25. (" Expeditious arbitration within the WTO as an alternative means of dispute settlement can facilitate the solution of certain disputes that concern issues that are clearly defined by both parties.")

[15]: According to Article 2 of the DSU: https://www.wto.org/english/docs_e/legal_e/28-

dsu_e.htm\#2. ("The Dispute Settlement Body is hereby established to administer these rules and procedures and, except as otherwise provided in a covered agreement, the consultation and dispute settlement provisions of the covered agreements.”) 